\title{
Colorectal Cancer: It Starts and It Runs
}

\author{
Rajunor Ettarh \\ Department of Structural and Cellular Biology, \\ Tulane University School of Medicine, New Orleans, \\ USA
}

\section{Introduction}

An automobile starts and runs. In much the same way, colorectal cancer starts and runs but our understanding of how this happens is incomplete. The disease affects millions of men and women around the world, and is responsible for significant morbidity and mortality in patients. Increasing numbers of new cases continue to appear worldwide and there is little evidence of a decline in incidence of the disease. The necessity for improved management and treatment of colorectal cancer in patients continues to drive studies and investigations towards a better understanding of the origins of the disease. Much of the evidence suggests that the origins of colorectal cancer are multifactorial: genetic and environmental factors intertwine with risk factors. Figure 1 lays out various aspects of colorectal cancer that provide broad focal points for studies and research investigations. In vitro studies have helped to define the scientific knowledge base regarding initiation of colorectal cancer and the mechanisms that sustain progression and encourage spread of the disease. Clinical studies and trials have provided insights into disease management and patient care. Animal modeling provides an important bridge between in vitro studies and investigations in patients. So what is the current state of the evidence regarding the causes and biological mechanisms involved in colorectal cancer? While the chapters in this volume of the book deliver detailed overviews of various aspects of the basic science involved in our understanding of the disease, this introductory chapter offers a summary outline of some of the evidence.

\section{Genes and heredity}

Genetic and hereditary mechanisms have a significant influence on colorectal cancer. Studies indicate that familial history plays a role in up to $25 \%$ of patients who are diagnosed with colorectal cancer (Gala \& Chung, 2011) and this helps to explain the origins of their disease. Several genes have been implicated in the process of colorectal carcinogenesis including adenomatous polyposis coli (APC), rat sarcoma oncogene K-ras, tumor suppressor TP53, DNA glycosylase gene MUTYH, and murine sarcoma oncogene BRAF. In many patients, the most frequently mutated gene is the APC gene (Bettstetter et al, 2007; Vasovcak et al, 2011). Some of the methods by which these genes are affected include hypermethylation of promoter sequences for tumor suppressor genes as well as the induction of microsatellite instability. About $15 \%$ of colorectal cancers show microsatellite instability from mutated mismatch repair genes (Pino \& Chung, 2011). 
A majority of colorectal cancers are associated with colonic polyposis. Familial adenomatous polyposis (FAP) confers a genetic predisposition to developing multiple benign polyps in the large intestine, a reflection of the inherited mutation in the APC gene. Polyps eventually progress to malignant colorectal cancer. Patients with Lynch Syndrome have a genetic predisposition that confers a high risk for developing early onset, right-sided colorectal cancer (Bellizzi \& Frankel, 2009). More recently recognized syndromes also include MUTYH-associated polyposis (MAP), and hyperplastic polyposis syndromes which show mutations of K-ras and microsatellite instability - changes similar to those associated with colorectal cancer (Hawkins et al, 2000; Jass et al, 2000; Liljegren et al, 2003).

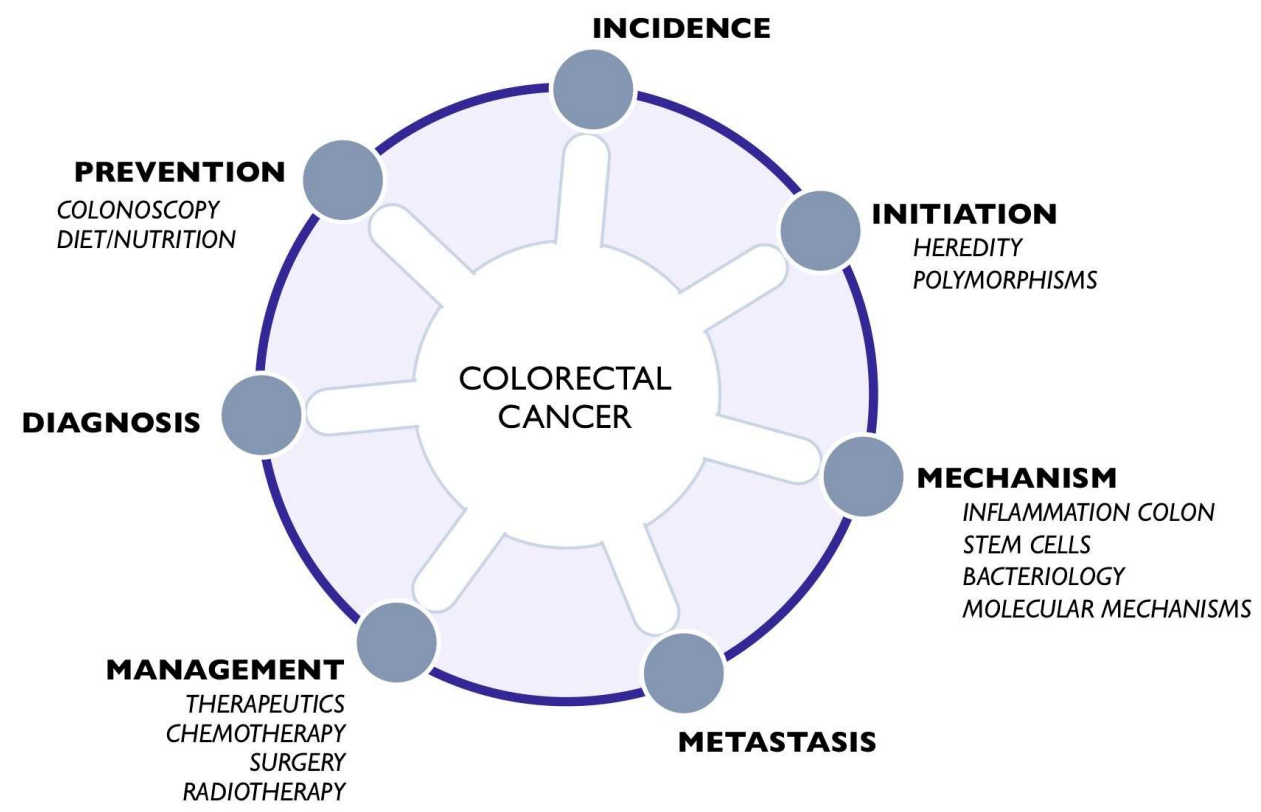

Fig. 1. The aspects of colorectal cancer that drive the quest for improved understanding, better management, effective therapies, and prevention. Aspects of initiation and mechanisms are considered in this volume of the book. Management, diagnosis and epidemiological considerations are dealt with in the second volume of the book.

Animal models of colorectal cancer have contributed to improving understanding of the disease. The APC min mouse model develops multiple intestinal polyps and illustrates the role of Wnt signaling and beta catenin regulation in the formation of these polyps (Kawahara et al, 2000; Senda et al, 2007). The model provides one avenue for testing and evaluating pharmacotherapeutic approaches in colorectal cancer.

\section{Nutrition}

The relationship between nutrition and colorectal cancer remains inconsistent and debatable. Some studies suggest variable colorectal cancer risk with ingestion of fruit and vegetables, other studies indicate a reduction in the risk (Millen et al, 2007; Koushik et al, 
2007; Anemma et al, 2011). The evidence is just as conflicting even when specific food components such as folate are considered (Mason, 2011). Some of the published data supports the association between colorectal cancer and processed foods as well as with consumption of red meat: the risk of colorectal cancer increases in line with increasing intake (Fu et al, 2011; Gingras and Beliveau, 2011). In addition, the risk among heavy alcohol drinkers for developing colorectal cancer is considerably higher than the risk for those whose alcohol intake is low (Pelluchi et al, 2011).

\section{Mechanisms}

The role of inflammation in colorectal cancer is demonstrated by the increased risk of colorectal in patients with chronic inflammatory conditions: the risk in patients with ulcerative colitis is 2-fold higher than for the general population and up to $0.8 \%$ of patients with Crohn's disease develop colorectal cancer (Pohl et al, 2000; Rizzo et al, 2011). These inflammatory diseases also demonstrate genetic alterations in some of the same targets associated with colorectal cancer. In addition, anti-inflammatory therapy significantly reduces the risk of colorectal cancer (Trinchieri, 2011).

The intestine is colonized by great numbers of microbes in a symbiotic relationship with the gut epithelium, a relationship that affects digestion, absorption and nutrition. Nonetheless, there is increasing evidence of the association between intestinal streptococcal infection and colorectal cancer. However the precise mechanism by which these streptococcal strains are involved in the development or propagation of colorectal cancer remains unclear (Boleij et al, 2011). Enteric microbes are thought to alter normal regulatory mechanisms in epithelial cells to promote disruption and tumor growth (Wu et al, 2003; Sun et al, 2004; Franco et al, 2005; Ye et al, 2007; Suzuki et al, 2009; Gnad et al, 2010; Liu et al, 2010).

The idea that colorectal cancer is sustained by stem cells that continually supply new tumor cells continues to spur research investigations and generate new data. The idea however remains controversial despite several reports presenting data on putative cell surface markers for these stem cells. Isolated colorectal cancer stem cells (initiating cells) express a variety of cluster of differentiation proteins or markers that suggest a multipotent ability (Willis et al, 2008; Kemper et al, 2010; Davies et al, 2011; Zeki et al, 2011) but identification of a reliable stem cell biomarker is still elusive. These cells offer a potential target for cure of the disease in patients and for the control of metastatic spread that is thought to arise from residual stem cells that survive therapy for the primary tumor.

\section{Conclusion}

Our understanding of colorectal cancer in terms of origination, genesis, initiating causes and progression continues to improve. While multiple factors contribute to and influence the initiation and progression of the disease, the number of potential targets continues to increase. This targeting potential will ultimately lead to the development of effective strategies for management of the disease and translate into improved treatments for patients.

\section{References}

Annema N, Heyworth JS, McNaughton SA, Iacopetta B, Fritschi L. (2011). Fruit and vegetable consumption and the risk of proximal colon, distal colon, and rectal 
cancers in a case-control study in Western Australia. J Am Diet Assoc, Vol.111, No.10, pp. 1479-1490.

Bellizzi AM, Frankel WL. (2009). Colorectal cancer due to deficiency in DNA mismatch repair function: a review. Adv Anat Pathol, Vol.16, No.6, pp. 405-417.

Bettstetter M, Dechant S, Ruemmele P, Grabowski M, Keller G, Holinski-Feder E, Hartmann A, Hofstaedter F, Dietmaier W. (2007). Distinction of hereditary nonpolyposis colorectal cancer and sporadic microsatellite-unstable colorectal cancer through quantification of MLH1 methylation by real-time PCR. Clin Cancer Res, Vol.13. No.11, pp. 3221-3228.

Boleij A, van Gelder MM, Swinkels DW, Tjalsma H. (2011). Clinical Importance of Streptococcus gallolyticus Infection Among Colorectal Cancer Patients: Systematic Review and Meta-analysis. Clin Infect Dis, Vol.53, No.9, pp. 870-878.

Davies EJ, Marsh V, Clarke AR. (2011). Origin and maintenance of the intestinal cancer stem cell. Mol Carcinog, Vol.50, No.4, pp. 254-263.

Franco AT, Israel DA, Washington MK, Krishna U, Fox JG, Rogers AB, Neish AS, CollierHyams L, Perez-Perez GI, Hatakeyama M, Whitehead R, Gaus K, O'Brien DP, Romero-Gallo J, Peek RM Jr. (2005). Activation of beta-catenin by carcinogenic helicobacter pylori. Proc Natl Acad Sci USA, Vol.102, pp. 10646-10651.

Fu Z, Shrubsole MJ, Smalley WE, Wu H, Chen Z, Shyr Y, Ness RM, Zheng W. (2011) Association of meat intake and meat-derived mutagen exposure with the risk of colorectal polyps by histologic type. Cancer Prev Res (Phila), Vol.4, No.10, pp. 16861697.

Gala M, Chung DC. (2011). Hereditary colon cancer syndromes. Semin Oncol, Vol.38, No.4, pp. 490-499.

Gingras D, Béliveau R. (2011) Colorectal cancer prevention through dietary and lifestyle modifications. Cancer Microenviron, Vol.4, No.2, pp. 133-139.

Gnad T, Feoktistova M, Leverkus M, Lendeckel U, Naumann M. (2010). Helicobacter pyloriinduced activation of beta-catenin involves low density lipoprotein receptor-related protein 6 and dishevelled. Mol Cancer, Vol.9, pp.31

Hawkins NJ, Gorman P, Tomlinson IPM, Bullpitt P, Ward RL. (2000). Colorectal Carcinomas Arising in the Hyperplastic Polyposis Syndrome Progress through the Chromosomal Instability Pathway. American Journal of Pathology, Vol.157, pp. 385392.

Jass JR, Lino H, Ruszkiewicz A, Painter D, Solomon MJ, Koorey DJ, Cohn D, Furlong KL, Walsh MD, Palazzo J, Edmonston TB, Fishel R, Young J, Leggett BA. (2000). Neoplastic progression occurs through mutator pathways in hyperplastic polyposis of the colorectum. Gut, Vol.47, pp. 43-49.

Kawahara K, Morishita T, Nakamura T, Hamada F, Toyoshima K, Akiyama T. (2000). Down-regulation of beta-catenin by the colorectal tumor suppressor APC requires association with Axin and beta-catenin. J Biol Chem, Vol.275, No.12, pp. 8369-8374.

Kemper K, Grandela C, Medema JP. (2010). Molecular identification and targeting of colorectal cancer stem cells. Oncotarget, Vol.1, No.6, pp. 387-395.

Koushik A, Hunter DJ, Spiegelman D, Beeson WL, van den Brandt PA, Buring JE, Calle EE, Cho E, Fraser GE, Freudenheim JL, Fuchs CS, Giovannucci EL, Goldbohm RA, Harnack L, Jacobs DR Jr, Kato I, Krogh V, Larsson SC, Leitzmann MF, Marshall JR, 
McCullough ML, Miller AB, Pietinen P, Rohan TE, Schatzkin A, Sieri S, Virtanen MJ, Wolk A, Zeleniuch-Jacquotte A, Zhang SM, Smith-Warner SA. (2007). Fruits, vegetables, and colon cancer risk in a pooled analysis of 14 cohort studies. J Natl Cancer Inst, Vol.99, No.19, pp. 1471-1483.

Liljegren A, Lindblom A, Rotstein S, Nilsson B, Rubio C, Jaramillo E. (2003). Prevalence and incidence of hyperplastic polyps and adenomas in familial colorectal cancer: correlation between the two types of colon polyps. Gut, Vol.52, No.8, pp. 11401147.

Liu X, Lu R, Wu S, Sun J. (2010). Salmonella regulation of intestinal stem cells through the Wnt/beta-catenin pathway. FEBS Lett, Vol.584, pp. 911-916

Mason JB. (2011). Unraveling the complex relationship between folate and cancer risk. Biofactors, Vol.37, No.4, pp. 253-260.

Millen AE, Subar AF, Graubard BI, Peters U, Hayes RB, Weissfeld JL, Yokochi LA, Ziegler RG; PLCO Cancer Screening Trial Project Team. (2007). Fruit and vegetable intake and prevalence of colorectal adenoma in a cancer screening trial. Am J Clin Nutr, Vol.86, No.6, pp. 1754-1764.

Pelucchi C, Tramacere I, Boffetta P, Negri E, La Vecchia C. (2011) Alcohol consumption and cancer risk. Nutr Cancer, Vol.63, No.7, pp. 983-990.

Pino MS, Chung DC. (2011). Microsatellite instability in the management of colorectal cancer. Expert Rev Gastroenterol Hepatol, Vol.5, No.3, pp. 385-399.

Pohl C, Hombach A, Kruis W. (2000). Chronic inflammatory bowel disease and cancer. Hepatogastroenterology, Vol.47, No.31, pp. 57-70.

Rizzo A, Pallone F, Monteleone G, Fantini MC. (2011). Intestinal inflammation and colorectal cancer: A double-edged sword? World J Gastroenterol. 17(26):3092-100.

Senda T, lizuka-Kogo A, Onouchi T, Shimomura A. (2007). Adenomatous polyposis coli (APC) plays multiple roles in the intestinal and colorectal epithelia. Med Mol Morphol, Vol.40, No.2, pp. 68-81.

Sun J, Hobert ME, Rao AS, Neish AS, Madara JL. (2004). Bacterial activation of beta-catenin signaling in human epithelia. Am J Physiol Gastrointest Liver Physiol, Vol.287, pp. G220-G227

Suzuki M, Mimuro H, Kiga K, Fukumatsu M, Ishijima N, Morikawa H, Nagai S, Koyasu S, Gilman RH, Kersulyte D, Berg DE, Sasakawa C. (2009). Helicobacter pylori CagA phosphorylation-independent function in epithelial proliferation and inflammation. Cell Host Microbe, Vol.5, pp. 23-34.

Trinchieri G. (2011) Innate inflammation and cancer: Is it time for cancer prevention? F1000 Med Rep, Vol.3, pp. 11.

Vasovcak P, Pavlikova K, Sedlacek Z, Skapa P, Kouda M, Hoch J, Krepelova A. (2011). Molecular genetic analysis of 103 sporadic colorectal tumours in czech patients. PLoS One, Vol.6, No.8, pp. e24114.

Willis ND, Przyborski SA, Hutchison CJ, Wilson RG. (2008) Colonic and colorectal cancer stem cells: progress in the search for putative biomarkers. J Anat, Vol.213, No.1, pp. 59-65.

Wu S, Morin PJ, Maouyo D, Sears CL. (2003). Bacteroides fragilis enterotoxin induces c-myc expression and cellular proliferation. Gastroenterology, Vol.124, pp. 392-400. 
Ye Z, Petrof EO, Boone D, Claud EC, Sun J. (2007). Salmonella effector avra regulation of colonic epithelial cell inflammation by deubiquitination. Am J Pathol, Vol.171, pp. 882-892

Zeki SS, Graham TA, Wright NA. (2011). Stem cells and their implications for colorectal cancer. Nat Rev Gastroenterol Hepatol, Vol.8, No.2, pp. 90-100 


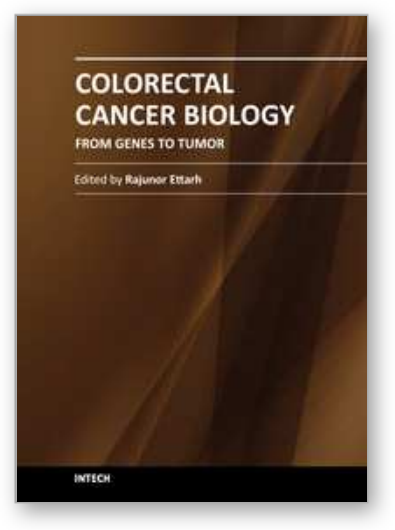

\author{
Colorectal Cancer Biology - From Genes to Tumor \\ Edited by Dr. Rajunor Ettarh
}

ISBN 978-953-51-0062-1

Hard cover, 446 pages

Publisher InTech

Published online 10, February, 2012

Published in print edition February, 2012

Colorectal cancer is a common disease, affecting millions worldwide and represents a global health problem. Effective therapeutic solutions and control measures for the disease will come from the collective research efforts of clinicians and scientists worldwide. This book presents the current status of the strides being made to understand the fundamental scientific basis of colorectal cancer. It provides contributions from scientists, clinicians and investigators from 20 different countries. The four sections of this volume examine the evidence and data in relation to genes and various polymorphisms, tumor microenvironment and infections associated with colorectal cancer. An increasingly better appreciation of the complex inter-connected basic biology of colorectal cancer will translate into effective measures for management and treatment of the disease. Research scientists and investigators as well as clinicians searching for a good understanding of the disease will find this book useful.

\title{
How to reference
}

In order to correctly reference this scholarly work, feel free to copy and paste the following:

Rajunor Ettarh (2012). Colorectal Cancer: It Starts and It Runs, Colorectal Cancer Biology - From Genes to Tumor, Dr. Rajunor Ettarh (Ed.), ISBN: 978-953-51-0062-1, InTech, Available from: http://www.intechopen.com/books/colorectal-cancer-biology-from-genes-to-tumor/colorectal-cancer-it-startsand-it-runs

\section{INTECH}

open science | open minds

\section{InTech Europe}

University Campus STeP Ri

Slavka Krautzeka 83/A

51000 Rijeka, Croatia

Phone: +385 (51) 770447

Fax: +385 (51) 686166

www.intechopen.com

\section{InTech China}

Unit 405, Office Block, Hotel Equatorial Shanghai

No.65, Yan An Road (West), Shanghai, 200040, China

中国上海市延安西路65号上海国际贵都大饭店办公楼 405 单元

Phone: +86-21-62489820

Fax: $+86-21-62489821$ 
(C) 2012 The Author(s). Licensee IntechOpen. This is an open access article distributed under the terms of the Creative Commons Attribution 3.0 License, which permits unrestricted use, distribution, and reproduction in any medium, provided the original work is properly cited. 